\title{
Women and Men's Legislative Success in 21st Century Professional and Citizen State Legislatures
}

\author{
Donald E. Whistler and Mark C. Ellickson
}

The bill-passage success of women and men legislators in professional and in citizen state legislatures is evaluated using a path analytical model. The model consists of exogenous personal, institutional, district, and state-level variables, an intervening variable of legislative leadership positions, and the direct and indirect effects of these variables on bill-passage success. With data from a 2004 survey of all fifty lower state houses compared to a similar 1992 nationwide survey of state legislators, women legislators display increased legislative positions and bill-passage in both professional and citizen state legislatures. The model predicts that institutional factors and, to a lesser extent, personal attributes are essential components for acquiring legislative positions as well as bill-passage success for women and men in both types of legislatures.

Beginning in the 1970s, bill-passage success among women legislators increased significantly as their membership and presence in state legislatures expanded (Thomas 1994). Moreover, the variables that predicted women's bill-passage success were similar for both women and men legislators (Ellickson and Whistler 2000). However, a leveling of women's membership has occurred in state legislatures since these studies were conducted with potentially serious implications for their success in the legislative process. Carroll (2007) expresses concern for the potentially "troubling development" of women's membership leveling:

Although women have made substantial progress over time in increasing their presence in state government, the leveling off of women's numbers among statewide elective officials and state legislatures in recent years is a puzzling and for many, a troubling development. ... (p. 444).

In light of the enhanced recognition women legislators place on issues of importance to women and a commitment to pursue these into public policies (Whistler and Ellickson 2010), among the potentially "troubling developments" is the possible impact of membership leveling on the enactment of women's legislative agendas. This article updates a study (Ellickson and Whistler 2000) of bill-passage success of women state legislators conducted during the last decade of the 20th century with data from the first decade of

DONALD E. WHISTLER is a professor of Political Science at University of Central Arkansas. MARK C. ELLICKSON is a professor of Political Science at Missouri State University.

The American Review of Politics, Vol. 32, Fall, 2011: 213-231

(C)2011 The American Review of Politics 
the 21 st century, expanding and evaluating an explanatory model of billpassage success for women and men legislators.

\section{Toward an Explanatory Model of Women's Bill-Passage Success}

\section{Conceptual Overview}

A legislator's bill-passage success is influenced by personal characteristics (e.g., personal ambition), constituency influences (e.g., urban-rural), institutional circumstances (e.g., seniority), and state-level variables (e.g., term-limits) (see Literature section).

Conceptually these variables array into a "funnel of causality" with personal, institutional, district, and state-level variables contributing the initial background influences on bill-passage success. Additionally, legislative leadership position - a variable known to enhance capacity to affect legislative agendas - conceptually may be an intervening variable for bill-passage; that is, holding a legislative leadership position is influenced by the background variables, which in turn becomes an asset for obtaining enactment of bills. This anticipated set of relationships (i.e., Model of Bill-Passage Success - Figure 1) is evaluated using path analysis that examines the direct and indirect influences of the background variables (exogenous) on legislative leadership (intervening) as well as on bill-passage success (dependent), and the direct and indirect influence of legislative leadership position on billpassage success.

The different procedures and conditions that exist within the two distinctive varieties of state legislative structures - professional or citizenmay channel/direct legislator's legislative efforts (and resulting bill-passage success rates). Consequently, we run separate analyses of the explanatory model of bill-passage success for women and for men legislators in each of these two types of legislatures.

\section{Literature}

Personal Attributes. A legislator's bill-passage success may be enhanced by formal education providing increased capacity to formulate and communicate complex ideas and situations more clearly than their less formally educated colleagues (Rosenthal 1989; Meyer 1980; Weissert 1991a). Moreover, the better educated are held in higher regard by their colleagues (Caldeira and Patterson 1988), and are more likely to be chosen as leaders. Women state legislators now have the same level of formal education as men, although men legislators continue to be more likely to possess a law background (Whistler and Ellickson 2004). 
Figure 1. Conceptual Model of Legislative Bill-Passage Success

Exogenous Variables

(Independent Variables)

\author{
Endogenous Variables
}

Personal Attributes

Education

Political Experience

Personality

Ideology

Political Ambition

Race

Occupation

Institutional Factors

Seniority

Legislative Networking

Majority Party

Parliamentary Expertise

Legislative Strategy

Obstructionist

Policy Generalist/Specialist

District Characteristics

Urban/Suburban/Rural

Racial/Ethnic Composition

District Wealth

\section{State-Level Features}

House District Population

Term Limits

Previous experience in government is another personal attribute that has been linked to a strong, positive relationship with success in the state legislature (Meyer 1980; Caldeira and Patterson 1988). During the past decade, previous political experience has increased both among women and men state legislators; presently each has about the same amount (Whistler and Ellickson 2004).

Assertive and competitive personality types (Type A) tend to outperform less competitive personality types (Type B) on tasks requiring persistence and endurance (Jex 1998); bill passage is such an activity. However, Type A personalities, while often high achievers, typically do not gain formal leadership status as traits associated with this personality tend to conflict with the requirements of leadership positions (Stahl 1983; 
Schermerhorn et al. 2008). Within the legislative setting, Type A personality traits have been associated with masculine leadership styles in contrast to Type B personality traits that are claimed to be feminine leadership traits and styles (C. Rosenthal 1998; Cammisa and Reingold 2004).

Ideological moderation has also been cited as a prerequisite to legislative success (Meyer 1980; Moore and Thomas 1991). Extremists tend to pursue their agendas regardless of chance for success. Politically ambitious representatives (those intending to seek higher office) would also seem to be less likely to attain positions of leadership and bill-passage success since such ambition would direct attention and energy away from legislative duties in a quest for publicity and personal aggrandizement (Matthews 1960). Women legislators are politically ambitious to the same extent as their male counterparts (Maestas 2000).

Evidence is limited and inconclusive as to the impact of race on billpassage success and formal leadership positions. While Bratton and Haynie (1999) found that African-American legislators in three of the six states they studied were significantly less likely than white legislators to get their legislation enacted (p. 658), other studies have discerned no significant differences in legislative success based on race (Hamel et al. 1983; Moncrief et al. 1991) or leadership success. Nevertheless, the dearth of minorities in many state legislatures does not prevent them from influencing in ways other than formal leadership positions or bill-passage (Parry and Miller 2006).

Unlike men, women legislators of the 1970s had mostly come from noncompetitive economic experiences, from voluntary organizations, and from public service or nonprofit economic situations. Today, women and men legislators continue to display a notable difference in the type of occupational background that they bring to the legislature. About two-thirds of women legislators have a noncompetitive occupational background, while about two-thirds of men legislators have a competitive occupational background (Whistler and Ellickson 2010). Consequently, we would expect greater legislative success to accrue according to each gender's primary occupational background, i.e., greater success for women from noncompetitive occupations and greater success for men from competitive occupational backgrounds.

Institutional Factors. While state legislatures are unique in many ways, ${ }^{1}$ they share operating procedures/situations that provide commonalities within which legislators operate. Seniority affects bill-passage success by producing a better understanding of the legislative process, enhancing peer recognition, and acquiring leadership positions (Meyer 1980; Squire 1988; Ellickson and Whistler 2002). Contrary to assumptions, women and men state legislators now have virtually the same number of years served in the lower houses of the state legislatures: mean number of years is 7.0 and 
7.7 respectively, while the median number of years is 6.0 for both groups in 2002-04. ${ }^{2}$ Majority party membership is also an aid to bill-passage success (Meyer 1980; Hamel et al. 1983; Moore and Thomas 1991; Clucas 2007). ${ }^{3}$

Voting against the wishes of the party leadership (obstructionism) is negatively associated with ability to pass one's legislation (Rosenthal 1981; Evans 1990) and would seem to be an obstacle in obtaining leadership positions. Men state legislators are slightly more likely to be obstructionists than women (Whistler and Ellickson 1999, 2004).

Policy specialization has been found to be associated with legislative success (Francis 1962; Meyer 1980; Moore and Thomas 1991). Policy specialists are concerned with a narrower range of issues upon which to focus their energy and expertise than policy generalists and are generally viewed as more competent (Weissert 1991b). Citizen legislatures, lacking large specialized staffs, should provide enhanced opportunities for policy specialists. Neither women nor men state legislators are likely to identify themselves as policy specialists, although women are slightly more inclined to do so (Whistler and Ellickson 1999, 2004).

Expertise in parliamentary procedures provides an advantage in billpassage (Blair and Stanley 1991, 497; Davidson and Oleszek 2006, 213). Men state legislators are more inclined to rate themselves as parliamentary experts than women (Whistler and Ellickson 1999, 2004).

In any type of legislature, the creation of coalitions is fundamental to lawmaking. Networking and the establishment of political friendship and trust are essential among lawmakers (Calderia and Patterson 1988; Ellickson and Whistler 2002) especially in citizen legislatures where party considerations are very weak or nonexistent. Building coalitions requires that legislators be willing to compromise, accommodate, reciprocate, and negotiate on matters of policy and substance (Caldeira et al. 1993). Women officeholders have been found to be more likely than their male counterparts to exhibit these types of institutional behaviors (Thomas 1994; C. Rosenthal 1998); although, recent studies have found no gender differences on these legislative decision-making styles (Blair and Stanley 1991; Reingold 1996).

District Characteristics. Characteristics of a legislator's district also have the potential to influence legislative success. Urban districts, especially those of lower SES, place heavy demands for constituency services, i.e., casework and pork, while rural and suburban districts are more likely to focus on legislative solutions (Jewell 1982). Women are more likely to be elected from suburban and urban districts, as well as from more wealthy districts (Whistler and Ellickson 1999, 2004). We anticipate that rural/suburban districts will enhance legislative success, especially for women legislators.

State-Level Features. Legislative districts with more dense populations generate a more complex set of interests for which a legislator must 
perform various legislative functions and that may reduce a legislator's capacity to focus on lawmaking (Rosenthal 1998). A second state-level variable that may affect a legislator's bill-passage success is term limits. ${ }^{4}$ Term limits restrict the time available for legislators to obtain personal goals (e.g., leadership positions) and constituency-desired policies. Obviously term limits reduce the effectiveness of seniority, although they do not entirely eliminate it and may continue to be helpful in bill-passage. Indeed, among novice legislators in term-limited legislatures, those with a modicum of experience may be advantaged in bill passage, and certainly are advantaged in obtaining leadership positions.

\section{Intervening Variable}

Serving in a formal leadership capacity (i.e., party leadership and/or committee leadership) is highly coveted not only for its prestige, but also as a means of influencing legislation (Clucas 1992). Legislative leaders have access to numerous sources of formal and informal power (Rosenthal 1981), and thus exert considerable influence upon the activities of the legislature (Jewell and Patterson 1986). The agenda-setting power of committee chairpersons is also widely recognized (Francis 1989), and prestigious committee assignments can allow legislators to become leading experts on select subjects thereby enhancing their special status among colleagues (Ellickson and Whistler 2002).

The fact that legislative leaders are viewed with greater respect and have enhanced reputations compared to non-leaders has been demonstrated in a number of state legislative studies (Meyer 1980; Hamel et al. 1983; Weissert 1991a; Caldeira et al. 1993). While leaders generally are expected not to operate the legislature for their personal benefit (Jewell 1982, 139-41), Frantzich (1979) notes that House leaders are more likely to get their bills passed than nonleaders (pp. 417, 421). Partisan control of leadership (especially in professional state legislatures) has been used increasingly as a tactic to benefit majority members in the next election (Rosenthal 1989, 90-91, 9394); majority party members, then, are advantaged in having the capacity to dominate leadership positions and to enact their requests. Similarly, having a power position on important committees is also an asset in obtaining benefits for constituents. An efficient way to meet constituency demands is by acquiring a seat on a committee that distributes money and projects-a budget and/or appropriations committee (Rosenthal 1989, 89). Leadership in the minority party may also carry status and assists for bill-success, although not as determinative as majority party status. 


\section{Professional versus Citizen Legislative Structures and Procedures}

Professional or citizen legislative structure circumscribes leadership selection and bill-passage procedure. Having full-time, paid legislators who meet annually assisted by a large number of full-time staff members, professional legislatures are structural accommodations to more densely populated states. ${ }^{5}$ Urbanism generates a large volume and diversity of social and economic interests, requiring more formalized legislative conflict resolution - organization (i.e., leadership positions) and operation of the legislative process for partisan advantage (i.e., political parties). Political parties are the principal method within the professional legislature by which conflict is resolved into public policies and through which legislators must attempt to achieve their legislative agendas. Citizen legislatures, serving sparser populations and less diverse social and economic interests, have part-time, minimally reimbursed members who meet biennially assisted by a small staff. With partisanship often quite low and personal networking operating largely in lieu of party networking, citizen legislatures organize their bill-passage procedure only nominally on the basis of majority-minority parties. Informal networking among legislators, while common in professional legislatures (even across party lines) is not as pervasive as the ephemeral coalitions that characterize bill-passage within citizen legislatures.

\section{Data Collection and Measurement}

The data were collected from a three-wave mail survey of the lower houses of all fifty state legislatures. The initial wave was mailed in late 2002 with follow-up waves sent in early 2003 and summer 2004. The overall response rate was 40 percent. $^{6}$ Our total sample contains 1859 respondents of which women comprise 26.5 percent $(n=492)$ and men 73.5 percent $(n=1367)$; these percentages are within 3 percent of the actual percentages of all women and men state legislators (which in 2002 were $23.4 \%$ women and $76.4 \%$ men). Confidence in the representativeness of our samples is further reinforced by their congruence with the known percentages of women and men Democrat and Republican state legislators: The 61 percent Democrat affiliation of women state legislators in our sample is precisely that reported for all women state legislators at the time of our survey (Center for American Women and Politics 2002); and the percentages of Democrat and Republican men state legislators in our sample are the same as those percentages among all state legislators: in our sample, 45.6 percent of men legislators identified themselves as Democrats and 53.9 percent as Republicans, among all men state legislators 54 percent are Republican and 46 percent are Democrat (Book of the States 2003, Table 3.3). 
Success in bill passage was operationalized as a legislator's (sponsor or co-sponsor) percentage of statewide bills (i.e., major bills) that passed the House chamber during the 20022003 legislative session. Because a legislator's "sphere of influence" is primarily located in the chamber in which he or she resides, bill passage in this study refers to a bill clearing the House chamber and not necessarily its passage into law.

We employ King's (2000) measure of professionalism in state legislatures to identify professional and citizen types. His interval ranking is based upon member pay, staff members per legislator and total days in session. To maximize the contrasts between the two polar types of state legislatures as well as to achieve sufficient sample sizes, we selected from our nationwide sample the fifteen most professional and fifteen most citizen legislatures.

Specific measures of the personal-political attributes, institutional factors, and formal position are described in the Appendix.

\section{Meeting Assumptions and Model Estimation}

Path analysis and least-squares multiple regression were used to estimate the parameters of the proposed model and to assess the pattern of linkages of the exogenous variables with the endogenous variables. An examination of the correlation matrixes for all four models revealed no correlations in excess of .46, a level well below the threshold of concern (Asher 1983).

The path analysis for each of the four models was conducted in several stages. First, leadership position and bill-passage success were regressed on all exogenous variables (i.e., personal attributes, institutional factors, district characteristics and state-level variables) and their direct effects were assessed. Next, hierarchical multiple regression was performed to reveal the indirect effects of these variables on bill-passage success, exogenous variables were entered into the regression equation in the first step, followed by leadership position in the second step. Exogenous variables that failed to achieve statistical significance $(\mathrm{p}<.05)$ with the intervening (leadership position) or dependent variable (bill-passage success) were eliminated from further analysis in order to trim the models and make them more parsimonious (Tables 1 through 4).

The amount of variation explained with respect to bill-passage success ranged from .07 (male-citizen) to .23 (female-citizen); variation explained with respect to leadership position ranged from .14 (male-citizen) to .34 (female-citizen). Notably, in all four models the role of leadership position as an important intervening variable was confirmed. The results of the path analyses for the four reduced models (i.e., women and men legislators in professional and in citizen legislature) are discussed in the findings section below. 


\section{Findings}

Our first research concern was the impact the recent leveling of women's membership in state legislatures may have had on women's capacity to enact their agenda. Our findings are that, if anything, women state legislators are even better situated in leadership and in bill-passage at the beginning of the 21st century than they were in during the 1970-90 period of their expanding membership: Relative to their numbers in state legislatures, by 1991-92 women had attained parity of leadership positions with men in both professional and citizen legislatures; and in the first decade of the 21 st century women exceeded their previous leadership status in both types of legislatures. Moreover, while by 1991-92 women members of both professional and citizen legislatures were slightly more likely to have their bills enacted than men, this accelerated somewhat in 2002-04.

Professional Legislatures-Women (Table 1). Coming from noncompetitive occupational backgrounds (-.28) and being strongly ideological (.35) with majority party status (.18) were the boosts for women obtaining leadership positions in professional legislatures in the first decade of the 21st century. A decade ago women in professional legislatures were benefited in obtaining leadership positions by attributes more typical in the legislative process: those of being a moderate (-.16) and having seniority (.48).

Table 1. Women in Professional State Legislatures-Reduced Model Effects of Antecedent Variables on Leadership Position and Bill-Passage Success (standardized regression coefficients)

\begin{tabular}{|l|c|c|c|c|}
\hline Antecedent Variables & $\begin{array}{c}\text { Leadership } \\
\text { Position }\end{array}$ & \multicolumn{3}{|c|}{ Bill-Passage Success } \\
\hline & & Direct & Indirect & Total \\
\hline Education & n.s. & & - & .30 \\
\hline Ideology & $.35^{* * *}$ & .22 & .06 & .28 \\
\hline Occupation & $-.28^{* * *}$ & $-.23^{*}$ & -.05 & -.28 \\
\hline Majority Party & $.18^{*}$ & $.20^{*}$ & .06 & .24 \\
\hline Policy Generalist/Specialist & n.s. & $-.22^{*}$ & & -.22 \\
\hline Leadership Position & & $.18^{\mathrm{t}}$ & & .18 \\
\hline
\end{tabular}

Note: $\mathrm{n}=138 ;{ }^{\mathrm{t}} \mathrm{p} \leq .10 * \mathrm{p} \leq .05 ; * * \mathrm{p} \leq .01 ; * * * \mathrm{p} \leq .001 ;$ Adj. $\mathrm{R}^{2}=.15$ (Leadership Position); Adj. $\mathrm{R}^{2}=.22$ (Bill-Passage Success); n.s. $=$ not significant. 
Currently women's success at bill passage in professional legislatures is enhanced by being more formally educated (.30), being moderate ideologically (.22), coming from a non-competitive occupation (-.23), being a legislative generalist (-.22), and holding a leadership position (.18), as well as majority party status (.20). Whereas a decade ago, women with more aggressive personalities (.14), who were not politically ambitious for higher office (-.20), but held a leadership position (.29) with majority party status (.22) and who were legislative obstructionists from time to time (.17) were more likely to get their bills enacted. Common to both eras for women to get their bills enacted in professional legislature are holding a leadership position and being in the majority party.

Professional Legislatures-Men (Table 2). As was the case a decade ago, men in professional legislatures are assisted in obtaining leadership and bill-passage by different assets than women. Currently, years of seniority (.36), majority party status (.10), voting consistently with one's party (-.11) and being a policy specialist (.11) are boosts to obtaining leadership positions, as are those men representing more densely populated districts (.29) and who are restricted by term limits (.10). Likewise for men a decade ago, leadership positions were more readily attained by those with higher seniority (.29) and majority party status (.21), but differed in that men a decade

\section{Table 2. Men in Professional State Legislatures-Reduced Model}

Effects of Antecedent Variables on Leadership Position and

Bill-Passage Success (standardized regression coefficients)

\begin{tabular}{|l|c|c|c|c|}
\hline Antecedent Variables & $\begin{array}{c}\text { Leadership } \\
\text { Position }\end{array}$ & \multicolumn{3}{|c|}{ Bill-Passage Success } \\
\hline \multicolumn{1}{|l|}{} & & Direct & Indirect & Total \\
\hline Education & n.s. & $-.19^{* * *}$ & - & -.19 \\
\hline Seniority & $.36^{* * *}$ & n.s. & .12 & .12 \\
\hline Majority Party & $.10^{*}$ & n.s. & .03 & .03 \\
\hline Obstructionist & n.s. & $-.14^{*}$ & & -.14 \\
\hline Policy Generalist/Specialist & $-.11^{*}$ & n.s. & .04 & .04 \\
\hline District Population & $.29^{* * *}$ & n.s. & .10 & .10 \\
\hline Term Limits & $.10^{*}$ & n.s. & .03 & .03 \\
\hline Leadership Position & & $.34^{* * *}$ & & .34 \\
\hline
\end{tabular}

Note: $\mathrm{n}=352 ; * \mathrm{p} \leq .05 ; * * \mathrm{p} \leq .01 ; * * * \mathrm{p} \leq .001 ;$ Adj. $\mathrm{R}^{2}=.23$ (Leadership Position); Adj. $\mathrm{R}^{2}=.15$ (Bill-Passage Success); n.s. = not significant. 
ago were assisted by having parliamentary expertise (.16), being an obstructionist (-.09) and representing a safe district (.11).

The pathways to bill success for men in 21 st century professional state legislatures are different from women members. Significant assets for men were less formal education (-.19) along with holding a leadership position (.34) and not being an obstructionist (-.14). In the previous era, white men (.15) with higher education (.10) who were party leaders (.13), from the majority party (.25), had networked (.17), and who were parliamentary experts (.12) were most successful at bill-passage.

Citizen Legislatures-Women (Table 3). Women in citizen legislatures of the 21 st century were assisted in obtaining leadership positions by several conditions. Ambitious women (.24) from a competitive private occupation (.43) who were willing to be obstructionists (.35) were significantly more likely to acquire a leadership position; additionally, women with years

Table 3. Women in Citizen State Legislatures-Reduced Model

Effects of Antecedent Variables on Leadership Position and

Bill-Passage Success (standardized regression coefficients)

\begin{tabular}{|l|c|c|c|c|}
\hline Antecedent Variables & $\begin{array}{c}\text { Leadership } \\
\text { Position }\end{array}$ & \multicolumn{3}{|c|}{ Bill-Passage Success } \\
\hline & & Direct & Indirect & Total \\
\hline Education & n.s. & $-.24^{*}$ & - & -.24 \\
\hline Political Ambition & $.24^{*}$ & n.s. & .04 & .04 \\
\hline Occupation & $.43^{* * *}$ & n.s. & .08 & .08 \\
\hline Urban/Suburban-Rural & n.s. & $.29^{*}$ & & .29 \\
\hline Racial/Ethnic Makeup & $.32^{* * *}$ & n.s. & .06 & .06 \\
\hline District Wealth (SES) & $-.39^{* * *}$ & n.s. & -.07 & -.07 \\
\hline Seniority & $.36^{* * *}$ & n.s. & .06 & .06 \\
\hline Majority Party & n.s. & $.28^{*}$ & & .28 \\
\hline Obstructionist & $.35^{* * *}$ & n.s. & .05 & .06 \\
\hline District Population & $.39^{* * *}$ & $-.32^{*}$ & .07 & -.25 \\
\hline Term Limits & $.29 * *$ & n.s. & .05 & .05 \\
\hline Leadership Position & & $.18^{\mathrm{t}}$ & & .18 \\
\hline
\end{tabular}

Note: $\mathrm{n}=142 ;{ }^{\mathrm{t}} \mathrm{p} \leq .10 * \mathrm{p} \leq .05 ; * * \mathrm{p} \leq .01 ; * * * \mathrm{p} \leq .001 ;$ Adj. $\mathrm{R}^{2}=.34$ (Leadership Position); Adj. $\mathrm{R}^{2}=.23$ (Bill-Passage Success); n.s. $=$ not significant. 
of seniority (.36), representing poorer (-.39) and white legislative districts (.32) and being term-limited (.29) were more likely to obtain a leadership position. A decade ago, women in citizen legislatures were more likely to obtain leadership positions if white (.15), ambitious (.27), possessing seniority (.45) and a policy generalist (-.22).

Regarding current citizen legislature women's bill-passage rates, having a leadership position (.18) enhances women getting their bills enacted as did less formal education (-.24), coming from the majority party (.28) and from a suburban/urban district (.29) that was less densely populated (-.32). A decade ago, women in citizen legislatures were assisted in their bill passage by being better educated (.16), having a leadership position (.14), having more seniority (.17), willing to compromise (.14), and being a policy specialist (.17).

Citizen Legislatures-Men (Table 4). Men in the 21st century citizen legislatures acquire leadership positions from assets within the legislative chamber: seniority (.21), networking (.11), majority party status (.25); as well as being boosted by representing a more densely populated district (.18) and being term limited (.12). In the previous decade, men were also assisted largely by assets within the chamber: seniority (.45), majority party (.10), parliamentary expertise (.12), and being a policy compromiser (.20); those men who were more aggressive (.09) and ambitious (.10) were also more

\section{Table 4. Men in Citizen State Legislatures-Reduced Model}

Effects of Antecedent Variables on Leadership Position and

Bill-Passage Success (standardized regression coefficients)

\begin{tabular}{|l|c|c|c|c|}
\hline Antecedent Variables & $\begin{array}{c}\text { Leadership } \\
\text { Position }\end{array}$ & \multicolumn{3}{|c|}{ Bill-Passage Success } \\
\hline \multicolumn{1}{|l|}{} & n.s. & $.16^{* *}$ & - & .16 \\
\hline Race & $.21^{* * *}$ & n.s. & .03 & .03 \\
\hline Seniority & $.11^{*}$ & n.s. & .01 & .01 \\
\hline Legislative Networking & $.25^{* * *}$ & $.10^{*}$ & .03 & .13 \\
\hline Majority Party & $.18^{* * *}$ & n.s. & .02 & .02 \\
\hline District Population & $.12^{*}$ & n.s. & .01 & .01 \\
\hline Term Limits & & $.12^{*}$ & & .12 \\
\hline Leadership Position & &
\end{tabular}

Note: $\mathrm{n}=460 ; * \mathrm{p} \leq .05 ; * * \mathrm{p} \leq .01 ; * * * \mathrm{p} \leq .001 ;$ Adj. $\mathrm{R}^{2}=.14$ (Leadership Position); Adj. $\mathrm{R}^{2}=.07$ (Bill-Passage Success); n.s. $=$ not significant. 
likely to acquire a leadership position in the citizen legislatures of the last decade of the 20th century.

In the 21st century, bill-passage success for men in citizen legislatures is augmented by race (white) (.16), majority party status (.10), and holding a leadership position in the legislature (.12). A decade ago, men in citizen legislatures found legislative success primarily through seniority (.30) and, to a lesser extent, holding a leadership position (.13), educational level (.13), networking (.11), being a member of the majority party (.11), and possessing an aggressive personality (.14).

\section{Summary and Conclusion}

This research is concerned with explaining women and men state legislator's bill-passage success. Variables demonstrated by research to be important or potentially important to a legislator's bill-passage success are included in a path analytical model that consists of exogenous variables (personal, institutional, district, and state-level) and an intervening variable (legislative leadership positions) evaluated for women and for men legislators in professional and citizen types of state legislatures. The impact of women's recent leveling of membership in state legislatures is studied with data from 1992 and 2004 surveys of lower state house members and an expanded model is evaluated.

The leveling of women's membership in state legislatures during the first decade of the 21 st century does not negatively impact their capacity to obtain their legislative agenda: Not only do women's bill-passage success continue in the first decade of the 21 st century, as in the early 1990 s, to be slightly higher than men's in both types of legislatures but also women's acquisition of legislative leadership positions is slightly higher.

The differing professional and citizen structures and procedures affect obtaining legislative positions and bill-passage success. Within professional legislatures, women's acquisition of leadership positions appears to have gone from being benefitted in the early 1990s by insider majority party status and seniority benefits to a more ideologically-based outsider boost in the 2000s. Women's success at bill passage in professional legislatures was in the early 1990s and remains, the time-honored methods of legislative activities (i.e., majority party status and seniority). For men in professional legislatures, the traditional legislative activities (i.e., seniority, majority party status, and negotiating) were in the early 1990s and remain important assets for both acquiring leadership positions, as well as getting bills enacted.

Within citizen legislatures where political parties are less utilized to organize the legislative process, individual legislator's characteristics and activities are important in acquiring leadership positions. Women in the 
citizen legislatures of the first decade of the 21st century, as was the case in the early 1990s, are boosted into leadership by being politically ambitious and willing to act against the majority party's preferences especially when pushed by poorer constituents with larger district populations (although no longer assisted by high seniority). At the same time in citizen legislatures, women are more likely to get their bills enacted in the early 2000 s, as in the early 1990s, when they operated within the typical practices of legislative politics (i.e., held leadership positions and had majority party status). Men in citizen legislatures acquired leadership positions in the early 1990s, as they had in the early 2000s by insider legislative activities, as well as using typical inside the legislature activities to be more likely to get their bills enacted.

It is noteworthy that term limits, added to the explanatory model because of greater prominence since our 1992 study, did not independently differentiate between women and men legislator's acquisition of legislative positions or bill-passage rates.

We conclude from the explanatory model that while there are some individual characteristics that appear to have assisted women or men legislators in the early 1990 s and in the early 2000 s, legislative process variablesdiffering somewhat between professional versus citizen legislatures-were (in the late 1990s) and remain (in the early 2000s) most important for acquiring leadership positions and bill-passage success, perhaps somewhat more so for men than for women. ${ }^{7}$

\section{APPENDIX}

The variables in this study are self-reported measures operationalized as follows:

PERSONAL ATTRIBUTES

Education: (1) high school/GED, (2) some college/technical training, (3) two-year Associates degree, (4) bachelor's degree, (5) graduate/professional school.

Race: (0) nonwhite, (1) white.

Previous Political Experience (appointive or elective): (0) no, (1) yes.

Personality: scored on a five-point scale ranging from (1) hard-driving/assertive to (5) laid-back/easy-going.

Political Ideology: (0) moderate, (1) extreme.

Political Ambition: (0) no plans to run for higher office within the next five years, (1) plan to run for higher office within the next five years.

Occupation: (0) noncompetitive, (1) competitive.

\section{DISTRICT CHARACTERISTICS}

District Type: (0) rural, (1) urban/suburban.

District Racial/Ethnic Composition: (0) mostly nonwhite, (1) mostly white.

District Wealth: scored on a five-point scale ranging from (1) very poor to (5) very wealthy. 


\section{APPENDIX (continued)}

INSTITUTIONAL FACTORS

Seniority: scored as number of years served in the House.

Legislative Networking: scored as the number of times per week, on average, attended informal meetings with other legislators to work out positions on bills.

Majority Party: (0) minority party, (1) majority party.

Parliamentary Expertise: scored on a five-point scale ranging from (1) "I know enough to get by" to (5) parliamentary expert.

Legislative Strategy: scored on a four-point scale ranging from (1) "never bargain or compromise to get my bills passed" to (4) "bargain and compromise often to get my bills passed."

Obstructionist: ("During the last legislative session, when your party opposed the other party on a vote, approximately what percentage of the time did you vote with your party?")

Policy Generalist-Specialist: (0) generalist (1) specialist.

\section{STATE LEVEL FEATURES}

House District Population (see Rosenthal 1998, 13-14).

Mean $=36,199$

Median $=27,770$

Standard Deviation $=34,710$

Range: 2,770 to 372,000

Term Limited: (0) no, (1) yes.

\section{LEADERSHIP POSITION (Intervening Variable)}

Measured using a seven-point scale incorporating both party and committee positions. Scored: (0) committee member only, (1) vice-chair of one or more committees, (2) chair of one or more committees, (3) party leader (e.g., speaker, floor leader, caucus chairperson, or whip). In addition, legislators who were members of "key committees" were awarded one point for each membership. Key committees were identified as tax, finance, or budget committees; education, health, or welfare committees; and the committee that selects members to standing committees.

\section{BILL-PASSAGE SUCCESS (Dependent Variable)}

Measured as the percentage of statewide bills that a legislator passed through the House chamber during the last legislative session (as sponsor or co-sponsor). Range: $0 \%$ to $100 \%$.

\section{NOTES}

${ }^{1}$ States have histories, social and economic conditions, political personages, and geographic boundaries that generate uniqueness. These produce state-by-state differences in politics and institutions; for example, see Erikson, Wright, and McIver (1993) and Stonecash (1999).

${ }^{2}$ This closure of seniority between women and men may be the result of term limits and the recent increase in Republicans replacing Democrats among men legislators. Turnover rates have not changed. 
${ }^{3}$ There was significant change in majority party control of state legislatures from 1991-92 (when we conducted our first survey) to 2004 (when we completed our second survey (see Data Section). In 1992, Democrats controlled 25 of the states' legislatures, Republicans 8, and 16 were split; by 2004, Republicans controlled 21, Democrats controlled 17, and 11 were split (NCSL 2008). This change in party control resulted from a significant shift in men legislators' party identification over that time. During that same time, women legislators remained at about the same 61 percent Democratic affiliation. Our data in both samples accurately represents the party situation; see the Data Section.

${ }^{4}$ Currently there are 15 states that term limit their legislatures: the professional legislatures of California, Florida, Michigan, and Ohio; the citizen legislatures of Arkansas, Maine, Montana, South Dakota, Oklahoma, Nevada, and Nebraska; and the hybrid legislatures of Colorado, Arizona, Missouri, and Louisiana.

${ }^{5}$ For changes in professionalism in state legislatures, see King (2000). For discussion of the measurement of professionalism, see Squire (2007).

${ }^{6}$ Kathleen Dolan and Lynne E. Ford $(1995,339)$ reported a $46 \%$ return rate for their nationwide study of women state legislators. Sue Thomas reported an overall return rate of $54 \%$ for her 1988 survey of legislators, but it was only of 12 states $(1994,43)$. Eric Uslaner and Ronald Weber $(1977,4)$ reported a 38\% response rate. Wayne Francis (1967, 108 ) reported a $52 \%$ response rate.

${ }^{7}$ Contrary to expectations, professionalizing state legislatures, did not enhance the opportunities of women to be elected (Squire 1992, 69). Because professional legislatures are associated with more heavily populated and urbanized states that make greater demands for public services (Kurtz 1992, 2; Mooney 1995), they require much greater campaign expenditures and time commitments (Rosenthal in Van Horn ed. 1993, 115-163). While there is no evidence that women receive less campaign money for state legislative office than men (Hogan 2001), the time commitment involved in legislative service is a critical concern (as are attitudes such as political interest) (Lawless and Fox 2004).

Within the legislative process, the initial claim was that women were disadvantaged by their fewer numbers within legislatures. However, research findings have been mixed (Bratton 2005, 100-102). Recent research has tended to find that fewer women members do not adversely affect women's leadership positions or their bill-passage success (Bratton 2005, 110-122). Similarly, early research finding that gender has been associated with different styles/strategies to obtain policy goals within the legislative context (Kathlene 1994; Thomas 1994; Reingold 1996; Cammisa and Reingold 2004) has been questioned by recent research (Whistler and Ellickson 2010).

Currently women state legislators are younger than the previous generation of women legislators, but they continue to be older than their male counterparts; women in professional legislatures are now possessed of more previous elective office experience than men, but not in citizen legislatures; women state legislators are generally better educated than men (although more lawyers among men provide them with a continued edge in "professional" education) (Dolan and Ford 1997, 147; Whistler and Ellickson 2004). Women state legislators remain somewhat more "hard-driving" than men in terms of personality. Urban districts are still more likely to elect women than are rural, with women in professional legislatures now most likely to be elected from suburban districts. Regardless of the type of legislature, women continue to be more liberal. And they are now more likely to seek reelection than men in each type of legislature, especially in professional legislatures. While most state legislators do not intend to seek higher office, women in professional legislatures are slightly more likely to remain where they are (Whistler and Ellickson 2004). 
In proportion to their numbers in the legislative chambers, women now hold positions of power - party, committee, leadership - at similar rates to men (Bratton 2005), although women are still somewhat over represented on committees dealing with women's issues (education and welfare) (Darcy 1996, 892), and are better positioned in professional legislatures than in citizen legislatures. Women in both types of legislatures are less likely to oppose their party's leadership, notably so in professional legislatures (Whistler and Ellickson 2004).

Both in professional and citizen type legislatures, women are somewhat more inclined to specialize in subject matter (particularly in professional legislatures) and to initiate legislation than men (especially in citizen legislatures). Women attend informal legislative meetings (networking) at the same rate as men, but in the formal legislative process they perceive themselves as possessing somewhat less parliamentary expertise (Whistler and Ellickson 2004).

\section{REFERENCES}

Asher, Herbert B. 1983. Causal Modeling, 2nd ed. Beverly Hills, CA: Sage.

Blair, Diane D., and Jeanie R. Stanley. 1991. Personal Relationships and Legislative Power: Male and Female Perceptions. Legislative Studies Quarterly 16:495-507.

Book of the States, 2003. Table 3.3: The Legislators: Numbers, Terms, and Party Affiliations. Lexington, KY: Council of State Governments.

Bratton, Kathleen A., and Kerry L. Haynie. 1999. Agenda Setting and Legislative Success in State Legislatures. Journal of Politics 61:658-679.

Bratton, Kathleen A. 2005. Critical Mass Theory Revisited: The Behavior and Success of Token Women in State Legislatures. Politics and Gender 1(1):97-125.

Calderia, Gregory A., John A. Clark, and Samuel C. Patterson. 1993. Political Respect in the Legislature. Legislative Studies Quarterly 18:3-28.

Calderia, Gregory A., and Samuel C. Patterson. 1988. Contours of Friendship and Respect in the Legislature. American Politics Quarterly 16: 466-485.

Cammisa, Anne Marie, and Beth Reingold. 2004. Women in State Legislatures and State Legislative Research: Beyond Sameness and Difference. State Politics and Policy Quarterly 4:181-210.

Carroll, Susan. 2007. Women in State Government: Historical Overview and Current Trends. www.csg.org/knowledgecenter/docs/WomeninStateGovernmentHistorical OverviewCurrentTrends-Carroll.pdf,

Center for American Women and Politics, 2002. Fact Sheet. New Brunswick, NJ: Rutgers University.

Clucas, Richard A. 1992. Legislative Leadership and Campaign Support in California. Legislative Studies Quarterly 17:265-283.

Clucas, Richard A. 2007. Legislative Professionalism and the Power of State House Leaders. State Politics and Policy Quarterly 7:1-19.

Darcy, R. 1996. Women in State Legislative Power Structure: Committee Chairs. Social Science Quarterly 77:888-911.

Davidson, Roger H., and Walter J. Oleszek. 2006. Congress \& Its Members. Washington, DC: Congressional Quarterly Press.

Dolan, Kathleen, and Lynne E. Ford. 1995. The Politics of Women State Legislators: A South/Non-South Comparison. Southeastern Political Review 23:333-348. 
Dolan, Kathleen, and Lynne E. Ford. 1997. Change and Continuity among Women State Legislators: Evidence From Three Decades. Political Research Quarterly 50:137151.

Ellickson, Mark C., and Donald E. Whistler. 2000. A Path Analysis of Legislative Success in Professional and Citizen Legislatures: A Gender Comparison. Women \& Politics 21:77-103.

Ellickson, Mark C., and Donald E. Whistler. 2002. Pathways to Political Respect in American State Legislatures. Politics \& Policy 30(3):502-523.

Erikson, Robert S., Gerald C. Wright, and John P. Mciver. 1993. Statehouse Democracy: Public Opinion and Policy in the American States. New York: Cambridge University Press.

Evans, Lawrence C. 1990. Obstruction, Reputation, and Legislative Strategy. Presented at the American Political Science Association, San Francisco, CA.

Erikson, Robert S., Gerald C. Wright, and John P. McIver. 1993. Statehouse Democracy: Public Opinion and Policy in the American States. New York: Cambridge University Press.

Francis, Wayne L. 1962. Influence and Interaction in a State Legislative Body. American Political Science Review 56:953-961.

Francis, Wayne L. 1967. Legislative Issues in the Fifty States: A Comparative Analysis. Chicago: Rand McNally.

Francis, Wayne L. 1989. The Legislative Committee Game: A Comparative Analysis of Fifty States. Columbus: Ohio State University Press.

Frantzich, Stephen E. 1979. Who Makes Our Laws? The Legislative Effectiveness of Members of the U.S. Congress. Legislative Studies Quarterly 4:409-428.

Hamm, Keith E., Robert Harmel, and Robert Thompson. 1983. Ethnic and Partisan Minorities in Two Southern State Legislatures. Legislative Studies Quarterly 8:177-189.

Hogan, Robert E. 2001. Campaign Spending by Men and Women Candidates for the State Legislature. Presented at the American Political Science Association, San Francisco, CA.

Jewell, Malcolm E. 1982. Representation in State Legislatures. Lexington: University Press of Kentucky.

Jewell, Malcolm E., and Samuel C. Patterson. 1986. The Legislative Process in the United States, 4th ed. New York: Random House.

Jex, Steve. 1998. Stress and Job performance. Thousand Oaks, CA: Sage.

Kathlene, Lyn. 1994. Power and Influence in State Legislative Policymaking: The Interaction of Gender and Position in Committee Hearing Debates. American Political Science Review 88:560-576.

King, James D. 2000. Changes in Professionalism in U.S. State Legislatures. Legislative Studies Quarterly 25(2):327-343.

Kurtz, Karl T. 1992. Understanding the Diversity of American State Legislatures. In APSA Legislative Studies Section Newsletter, Extension of Remarks, 15:2-5.

Lawless, Jennifer, and Richard Fox, 2004. Why Don't Women Run? Providence, RI: Brown University, Taubman Center for Public Policy.

Maestas, Cherie. 2000. Professional Legislatures and Ambitious Politicians: Policy Responsiveness of State Institutions. Legislative Studies Quarterly 25(2):663-690.

Matthews, Donald R. 1960. U.S. Senators and Their World. New York: Vintage.

Meyer, Katherine. 1980. Legislative Influence: Toward Theory Development through Causal Analysis. Legislative Studies Quarterly 5:563-585. 
Moncrief, Gary, Joel Thompson, and Robert Schuhmann. 1991. Gender, Race, and the State Legislature: A Research Note on the Double Disadvantage Hypothesis. The Social Science Journal 28:481-487.

Mooney, Christopher Z. 1995. Citizens, Structures, and Sister States: Influences on State Legislative Professionalism. Legislative Studies Quarterly 20:47-67.

Moore, Michael K., and Sue Thomas. 1991. Explaining Legislative Success in the U.S. Senate: The Role of the Majority and Minority Parties. Western Political Quarterly 44:959-970.

Parry, Janine A. and William H. Miller. 2006. 'The Great Negro State of the Country?': Black Legislators in Arkansas, 1973-2000. Journal of Black Studies 36(2):833-882.

Reingold, Beth. 1996. Conflict and Cooperation: Legislative Strategies and Concepts of Power Among Female and Male State Legislators. The Journal of Politics 58:464485.

Rosenthal, Alan. 1981. Legislative Life. New York: Harper and Row.

Rosenthal, Alan. 1998. The Decline of Representative Democracy. Washington, DC: Congressional Quarterly Press.

Rosenthal, Alan. 1989. The Legislative Institution: Transformed and at Risk. In The State of the States, ed. Carl E. Horn. Washington DC: Congressional Quarterly Press.

Rosenthal, Alan. 1993. The Legislative Institution: Transformed and at Risk. In The State of the States, 2nd ed. Carl E. Horn ed. Washington DC: Congressional Quarterly Press.

Rosenthal, Cindy Simon. 1998. When Women Lead: Integrative Leadership in State Legislatures. New York: Oxford University Press.

Schermerhorn, John R., James G. Hunt, and Richard N. Osborn. 2008. Organizational Behavior, 10th ed. New York: Wiley.

Stahl, Michael J. 1983. Achievement, Power, and Managerial Motivation: Selecting Managerial Talent With the Job Choice Exercise. Personnel Psychology (Winter):775790.

Stonecash, Jeffrey. 1999. Political Cleavage in U.S. State Legislative Houses, Legislative Studies Quarterly 24(2):281-302.

Squire, Peverill. 1988. Member Career Opportunities and the Internal Organization of Legislatures. Journal of Politics 50:726-744.

Squire, Peverill. 2007. Measuring State Legislative Professionalism: The Squire Index Revisited. State Politics and Policy Quarterly 7(2):211-227.

Thomas, Sue. 1994. How Women Legislate. New York: Oxford University Press.

Uslander, Eric, and Robert Weber. 1977. Patterns of Decision Making in State Legislatures. New York: Praeger.

Weissert, Carol S. 1991a. Determinants and Outcomes of State Legislative Effectiveness. Social Science Quarterly 72:797-806.

Weissert, Carol S. 1991b. Policy Entrepreneurs, Policy Opportunists, and Legislative Effectiveness. American Politics Quarterly 19:262-274.

Whistler, Donald E., and Mark C. Ellickson. 1999. The Incorporation of Women in State Legislatures. Women \& Politics 20:81-97.

Whistler, Donald E., and Mark C. Ellickson. 2004. The Incorporation of Women into State Legislatures at the New Millennium: Preliminary Data. Presented at the Annual Conference of the Arkansas Political Science Association, University of Arkansas in Fayetteville, Arkansas. February 19-20.

Whistler, Donald E., and Mark C. Ellickson. 2010. A Rational Choice Approach to Explaining Policy Preferences and Concern for Representing Women among State Legislators. Politics \& Politics 38(1):25-51. 